\title{
Regulation of apoptosis by XIAP ubiquitin-ligase activity
}

\author{
Andrew J. Schile, María García-Fernández, and Hermann Steller ${ }^{1}$ \\ Howard Hughes Medical Institute, The Rockefeller University, New York, New York 10065, USA
}

\begin{abstract}
Inhibitor of Apoptosis Proteins (IAPs) can bind to and inhibit caspases, the key executioners of apoptosis. Because IAPs are frequently overexpressed in human tumors, they have become major pharmacological targets for developing new cancer therapeutics. However, the precise physiological function of individual mammalian IAPs and their role as E3 ubiquitin-ligases in situ remain largely obscure. Here, we investigated the function of XIAP ubiquitin-ligase activity by inactivating the RING motif via gene targeting in the mouse. Removing the RING stabilized XIAP in apoptotic thymocytes, demonstrating that XIAP ubiquitin-ligase activity is a major determinant of XIAP protein stability. Surprisingly, the increased amounts of "XIAP-BIR-only" protein did not lead to attenuated but rather increased caspase activity and apoptosis. $\Delta R I N G$ embryonic stem cells and fibroblasts had elevated caspase-3 enzyme activity, and XIAP $\triangle R I N G$ embryonic fibroblasts were strongly sensitized to TNF- $\alpha$-induced apoptosis. Similar results were obtained with XIAP deficient mice. Furthermore, deletion of the RING also improved the survival of mice in the E $\mu-M y c$ lymphoma model. This demonstrates a physiological requirement of XIAP ubiquitin-ligase activity for the inhibition of caspases and for tumor suppression in vivo.
\end{abstract}

[Keywords: XIAP; ubiquitin; caspase; apoptosis; cancer; lymphoma]

Supplemental material is available at http://www.genesdev.org.

Received February 14, 2008; revised version accepted June 25, 2008.

Virtually all animal cells have the ability to self-destruct by undergoing apoptosis, a morphologically distinct form of programmed cell death (Steller 1995). The proper regulation of apoptosis is critical for both development and tissue homeostasis, and inhibition of apoptosis contributes to the development and progression of cancer (Thompson 1995; Jacobson et al. 1997; Hanahan and Weinberg 2000; Degenhardt and White 2006). A central step for the execution of apoptosis is the activation of caspases, a family of proteases that are ubiquitously expressed as weakly active zymogens (Thornberry and Lazebnik 1998; Salvesen and Abrams 2004). Caspases can be activated in response to many different stimuli, including developmental signals as well as various forms of cellular stress or injury, including DNA damage, unfolded proteins, and oncogene activation (Bergmann et al. 1998; Adams and Cory 2007). In addition, caspases are also subject to negative regulation by inhibitors. One important family of negative caspase regulators are the Inhibitor of Apoptosis Proteins (IAPs) (Miller 1999). IAPs are characterized by the presence of at least one BIR (baculovirus inhibitory repeat) domain, which can directly bind to and inhibit caspases (Salvesen and Duckett 2002). Because IAPs are frequently overexpressed in hu-

${ }^{1}$ Corresponding author.

E-MAIL steller@mail.rockefeller.edu; FAX (212) 327-7076.

Article is online at http://www.genesdev.org/cgi/doi/10.1101/gad.1663108. man tumors and promote cancer cell survival, they have become major targets for developing new cancer therapeutics (Reed 2003; Vucic and Fairbrother 2007). The best studied mammalian IAP is the X-linked inhibitor of apoptosis (XIAP) protein, which is considered the most potent caspase inhibitor in vitro (Eckelman and Salvesen 2006). XIAP can inhibit a broad range of caspases within both mitochondrial and death receptor signaling pathways (Deveraux et al. 1998). A peptide sequence that includes the second BIR domain binds to and inhibits active caspase- 3 and caspase- 7 by occluding their active sites (Riedl et al. 2001; Scott et al. 2005), while the third BIR binds caspase- 9 in the apoptosome and prevents it from forming functional dimers (Shiozaki et al. 2003). While most of the attention has been focused on the BIR domains, XIAP also contains a RING motif that is the hallmark of E3 ubiquitin-ligases (Joazeiro and Weissman 2000), and RING function has been implicated in XIAP degradation during thymocyte apoptosis (Yang et al. 2000). However, much remains to be learned about the physiological function of XIAP (and other mammalian IAPs) in vivo. Several IAPs, including XIAP, cIAP1, and cIAP2, have been inactivated individually by targeted gene disruption in mice, but no significant apoptotic phenotypes have been reported previously (Harlin et al. 2001; Conze et al. 2005; Conte et al. 2006). Although $X I A P$ deficiency sensitizes sympathetic neurons to cytochrome-c-induced apoptosis (Potts et al. 2003), mutant 
mice are viable and appear phenotypically normal (Harlin et al. 2001).

Much of what we know about the physiological function and regulation of IAPs in vivo has come from genetic studies in Drosophila (Cashio et al. 2005; Kornbluth and White 2005). The activity of Drosophila IAP-1 (Diap1) is strictly required for the survival of virtually all somatic cells, and Diap1 mutant cells rapidly undergo caspase-dependent apoptosis (Wang et al. 1999; Goyal et al. 2000; Lisi et al. 2000). Furthermore, Diap1 functions as an E3 ubiquitin-ligase for regulating cell death and survival, both to target the caspase-9 ortholog Dronc for degradation in living cells, and to promote self-conjugation and Diap1 degradation under apoptotic conditions (Ryoo et al. 2002, 2004; Wilson et al. 2002). In the absence of Diap1 RING function, Diap1 is stabilized and its protein levels are increased, but the net outcome for most cells is still excessive cell death due to highly elevated Dronc levels (Ryoo et al. 2004). The induction of apoptosis in Drosophila requires the combined activity of three closely linked IAP antagonists, Reaper, Hid, and Grim (White et al. 1994; Grether et al. 1995; Chen et al. 1996). Reaper family proteins act as central integrators to relay information from many different signaling pathways to the core cell death program (Song and Steller 1999; Kornbluth and White 2005). Reaper family proteins directly bind to and inhibit the anti-apoptotic activity of Diap1 (Wang et al. 1999; Goyal et al. 2000). Furthermore, Reaper promotes the autoubiquitination and degradation of Diap1, thereby removing the "brakes on death" (Ryoo et al. 2002). Reaper family proteins use a structurally conserved $\mathrm{N}$-terminal IAP-binding motif (IBM) to bind BIR domains (Shi 2002). Functionally related IAP antagonists that can liberate caspases by competing for binding sites on the BIR domains have been found in mammals as well, including Smac/DIABLO and Omi/HtrA2 (Vaux and Silke 2003). Like in Drosophila, these proteins use a short N-terminal IBM for IAP binding and inhibition. However, elimination of either Smac/ DIABLO, Omi/HtrA2, or both together in double-mutant mice did not cause increased resistance toward apoptosis (Okada et al. 2002; Jones et al. 2003; Martins et al. 2004). Therefore, a physiological role of these proteins for regulating IAPs remains to be established, but this is possibly masked due to functional redundancy and the presence of additional IAP antagonists, such as ARTS (Larisch et al. 2000; Gottfried et al. 2004).

Mammalian XIAP shares several properties with Drosophila Diap1, including the ability to bind to caspases, to Reaper family proteins, and the ability to undergo autoubiquitination and proteasome-mediated degradation in response to apoptotic stimuli (Yang et al. 2000). Since these conclusions stem largely from overexpression and in vitro experiments, we decided to examine the role of XIAP E3-ligase activity for caspase regulation and apoptosis in vivo. For this purpose, we used gene targeting to generate a mouse XIAP $\triangle R I N G$ allele, which uncouples the caspase-binding properties of XIAP from the ubiquitin system, and compared it with the XIAP-null allele (Harlin et al. 2001). As expected, removing the RING stabilized XIAP in apoptotic thymocytes, demonstrating that XIAP E3-ligase activity is a major determinant of XIAP protein stability in vivo. Surprisingly, the elevated XIAP-BIR protein did not lead to increased inhibition of caspases or apoptosis, as would have been expected based on the prevailing view that the BIR domains of XIAP are sufficient for caspase inhibition (Eckelman and Salvesen 2006). On the contrary, $\triangle R I N G$ embryonic stem (ES) cells and fibroblasts had elevated caspase- 3 enzyme activity and impaired ubiquitination of active caspase-3 during apoptosis. Furthermore, XIAP $\triangle R I N G$ embryonic fibroblasts were strongly sensitized to TNF- $\alpha$ apoptosis, to the same extent as XIAP-null primary fibroblasts. Therefore, XIAP RING function plays an important physiological role for inhibition of caspases and apoptosis in certain cell types. Finally, deletion of the XIAP RING also significantly increased apoptosis of proliferating $\mathrm{B}$ cells and improved the survival of mice in a mouse lymphoma model. We conclude that the E3-ligase activity of XIAP is important for the regulation of apoptosis in at least some cell types in vivo, and that this activity contributes to tumor suppression. These results suggest that the XIAP RING may be a promising drug target for developing a novel class of cancer therapeutics.

\section{Results}

The $\triangle$ RING mutation generates a truncated XIAP protein

We used gene targeting to create a $\triangle$ RING truncation by replacing the first two amino acids (C449 and K450) of the mouse XIAP RING domain with stop codons (Fig. 1A). Direct sequencing of the genomic locus verified the presence of stop codons in targeted ES cells (Fig. 1B), and chimeric mice transmitted the mutant allele through the germline (Fig. 1C). The mutant allele encoded a truncated protein of the expected size that was expressed at similar levels as full-length XIAP in ES cells (Fig. 1D). $\triangle R I N G$ mice were fertile and born at expected Mendelian ratios for gender and genotype. The histopathology of mutant mice was indistinguishable from wild-type littermates at different ages, and $\triangle R I N G$ mice have shown no overt susceptibility to disease in our pathogen-free mouse colony after $>18$ mo of age. These observations are consistent with those seen in XIAP-null mice, which develop mostly normally (Harlin et al. 2001; Olayioye et al. 2005).

The RING is the primary determinant of XIAP stability during thymocyte apoptosis

XIAP and cIAP1 RING domains can serve as E3 ubiquitin-ligases to promote autoubiquitination and IAP degradation during mouse thymocyte apoptosis (Yang et al. 2000). Additionally, $\Delta$ RING XIAP mutant protein is resistant to ubiquitination, stably expressed, and imparts resistance to apoptosis when overexpressed in a mouse T-cell hybridoma (Yang et al. 2000). The observation that 


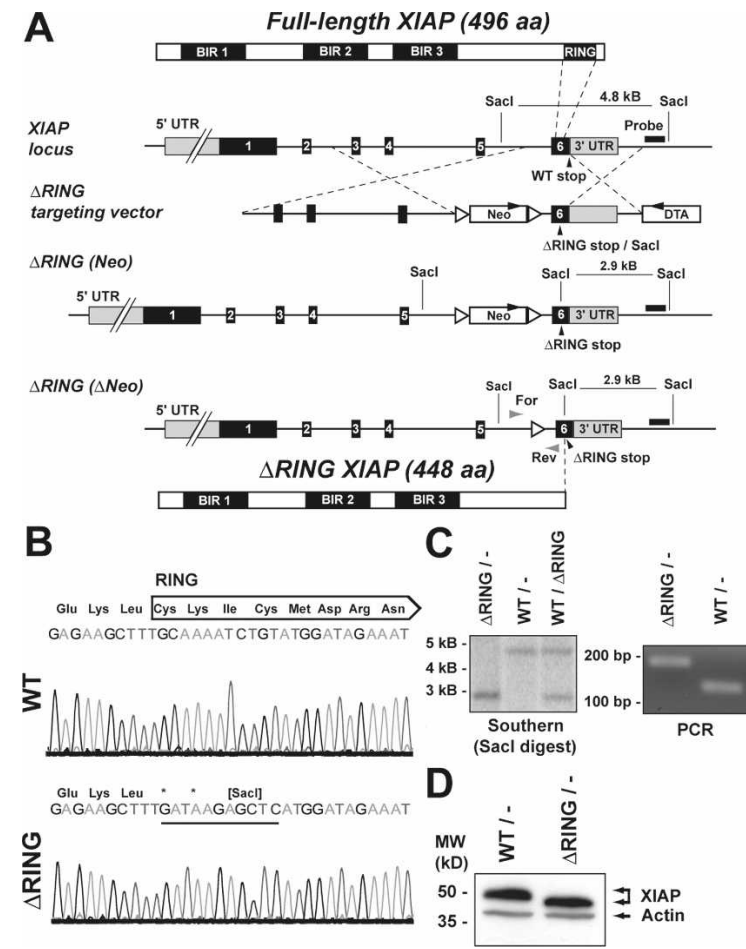

Figure 1. Engineering the $\triangle R I N G$ allele. $(A)$ Diagrams of the mouse XIAP genomic locus, targeting vector, and mutant allele. FRT sites are indicated by hollow triangles and the location of PCR genotyping primers are shown as gray arrowheads. $(B)$ DNA sequencing chromatograph showing replacement of the first two amino acids of the RING with tandem stop codons (each indicated by an asterisk) and the diagnostic SacI restriction site in mutant ES cells. The altered DNA is underlined in the $\triangle R I N G$ panel. (C, left panel) Southern blotting of genomic tail DNA digested with SacI showing the $\triangle R I N G$ allele in a hemizygous male and heterozygous female animal. (Right panel) PCR genotyping of mice. (D) Immunoblot of wild-type and $\triangle R I N G$ ES cells.

efficient thymocyte apoptosis requires the proteasome (Grimm et al. 1996) led to a hypothesis that IAP RINGs may act proapoptotically in these cells by engaging the ubiquitin system to relieve a break on cell death pathways by degrading IAPs (Yang and Li 2000). If this hypothesis were correct, thymocytes from the $\triangle R I N G$ mouse should have elevated XIAP protein levels and should be more resistant toward apoptosis (Silke et al. 2005). However, we were unable to detect any impairment of thymocyte apoptosis in several paradigms (Fig. 2). Although $\triangle$ RING XIAP protein was more stable than full-length XIAP in cultured thymocytes upon treatment with either dexamethasone or etoposide (Fig. 2A), deletion of the RING did not inhibit apoptosis (Fig. 2C-E). The basal expression of $\triangle$ RING XIAP was greater, and it was cleaved over time during apoptosis. In addition, deletion of the RING did not alter the basal expression or down-regulation of cIAP1 during apoptosis (Fig. 2A). XIAP and cIAP1 can bind each other in a RING-dependent manner (Silke et al. 2005), but our results indicate that removing the XIAP RING does not influence the abundance of cIAP1 in thymocytes, similar to what has been reported for XIAP-null thymocytes (Conze et al. 2005). Furthermore, XIAP $\triangle R I N G$ thymocytes still degraded Smac/DIABLO by the ubiquitin system (Fig. 2A; data not shown). Consistent with prior reports (Yang et al. 2000), the proteasome inhibitor MG-132 blocked the decrease of full-length XIAP during apoptosis while the pan-caspase inhibitor zVAD-fmk had negligible effects (Fig. 2B). $\triangle$ RING XIAP expression was more sensitive to caspase inhibition, however, as zVAD-fmk fully prevented the decrease in protein levels and abolished the cleavage product, while MG-132 had a lesser effect by comparison (Fig. 2B). This supports the hypothesis that the RING engages the ubiquitin system to promote XIAP turnover in apoptotic thymocytes.

$\triangle$ RING XIAP efficiently blocks glucocorticoid-induced apoptosis when expressed in a T-cell hybridoma (Yang et al. 2000). We used $\Delta R I N G$ thymocytes to see if this also occurs in primary cells. We labeled the active site of caspase- 3 with a fluorescent FAM-DEVD-FMK af-

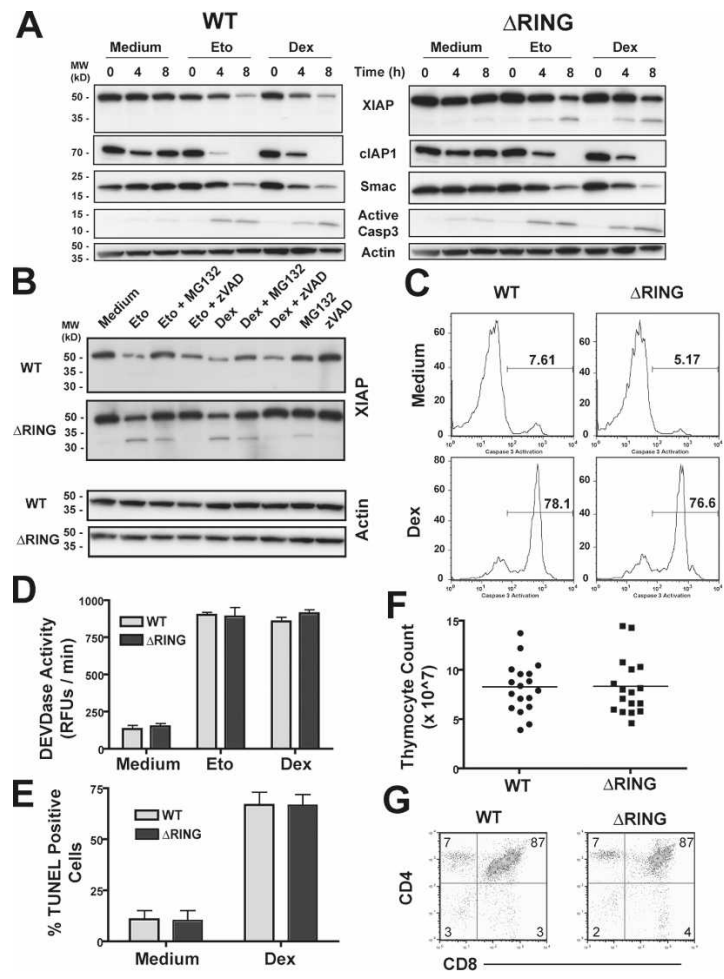

Figure 2. Deletion of the RING stabilizes XIAP during thymocyte apoptosis. (A) Immunoblotting of wild-type and $\Delta$ RING thymocytes treated with etoposide, dexamethasone, or left untreated for indicated times. $(B)$ Immunoblotting of thymocytes treated for $8 \mathrm{~h}$ with etoposide or dexamethasone, with or without the proteasome inhibitor MG-132 or the pan-caspase inhibitor zVAD-fmk. $(C)$ Fluorescent affinity labeling of the caspase-3 active site with the FAM-DEVD-fmk reagent to measure caspase activation. $(D)$ Bulk caspase-3-like activity after 8 h. $(E)$ Apoptosis after $8 \mathrm{~h}$ measured by the TUNEL assay. $(F)$ Total thymocyte counts in 4- to 6-wk-old mice; the black bar indicates the mean count. $(G)$ Thymus composition determined by flow cytometry using surface markers. 
finity tag to count the number of apoptotic wild-type and $\Delta R I N G$ thymocytes. Caspase-3 activation was unaltered in untreated and dexamethasone-treated $\triangle R I N G$ thymocytes (Fig. 2C). Caspase-3 enzyme activity (Fig. 2D) and apoptosis (Fig. 2E) were also comparable in dying cells of both genotypes. Total thymocyte counts were equal in 4to 6-wk-old wild-type and $\triangle R I N G$ mice (Fig. 2F), as were the distributions of major cell populations in the thymus (Fig. 2G). These data imply that the RING was important for XIAP protein stability in thymocytes, but its removal affected neither the development of the thymus nor the apoptosis of thymocytes in response to several stimuli. In this cell type, removing XIAP RING function did not reveal any specific proapoptotic role for ubiquitin-mediated XIAP turnover during cell death, and other labile proteins like cIAP1 and Smac were not affected. Likewise, XIAP-null mice have no detectable defects in thymocyte apoptosis (Harlin et al. 2001).

Elevated caspase-3 activity and reduced caspase-3 polyubiquitination in cultured $\triangle$ RING embryonic cells during apoptosis

Next we investigated whether XIAP function is required for caspase regulation and apoptosis in other cell types. For this purpose, we focused on ES cells and primary fibroblasts (MEFs [mouse embryonic fibroblasts]). $\triangle R I N G$ ES cells and MEFs displayed significantly elevated caspase- 3 enzyme when exposed to different apoptotic stimuli (Fig. 3A). However, the increased caspase- 3 activity was not associated with increased death of embryonic cells (Fig. 3B-D). Also, in spite of the elevated caspase- 3 enzyme activity in $\triangle R I N G$ cells, the native and cleaved forms of different caspases were expressed similarly in untreated and apoptotic ES cells (Fig. 3D) and MEFs (Fig. 3E). While XIAP, cIAP1, and Smac/ DIABLO became labile during thymocyte apoptosis, the expression levels of these proteins did not change much during ES cell apoptosis (Fig. 3D). MEFs are primed to undergo apoptosis following oncogenic transformation (Harrington et al. 1994; White 2001). We generated polyclonal pools of transformed wild-type and $\triangle R I N G$ MEFs by retroviral transduction of RasV12 and E1A to see if the transformed state might sensitize $\triangle R I N G$ MEFs to apoptosis. Indeed, different apoptotic stimuli caused elevated caspase activity in transformed $\triangle R I N G$ MEFs, and apoptosis occurred at earlier time points and lower drug concentrations than with primary cells (Supplemental Fig. 1A). Deletion of the XIAP RING led to elevated spontaneous apoptosis of transformed MEFs, but not in response to etoposide or UVC (Supplemental Fig. 1B,D).

XIAP can polyubiquitinate caspase- 3 when it is overexpressed (Suzuki et al. 2001), and the Diap1 RING has a critical function in ubiquitinating the caspase-9 ortholog Dronc in Drosophila (Wilson et al. 2002). Therefore, we asked if genetic deletion of the RING affected caspase-3 ubiquitination in apoptotic cells. For this purpose, we used an antibody that recognizes both full-length
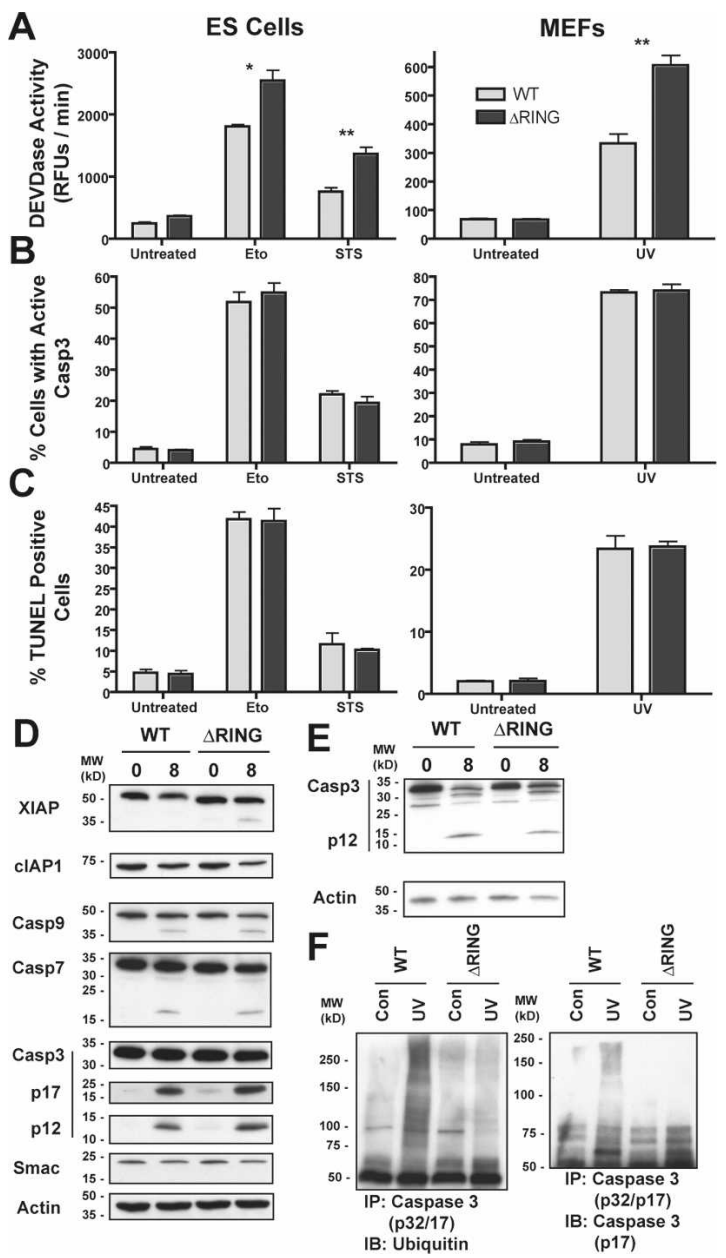

Figure 3. Caspase-3 activity is greater in $\triangle R I N G$ embryonic cells. (A) Caspase-3-like enzyme activity in bulk populations of wild-type and $\triangle R I N G$ ES cells treated for $10 \mathrm{~h}$ with etoposide or staurosporine (left) and MEFs irradiated with UVC after $8 \mathrm{~h}$ (right). $\left(^{\star}\right) P<0.05 ;\left({ }^{\star \star}\right) P<0.01$. (B) The percentages of cells with active caspase-3 as assessed by indirect immunofluoresence. $(C)$ Apoptosis measured by the TUNEL assay. (D) Immunoblotting of wild-type and $\triangle R I N G$ ES cells after etoposide treatment as indicated. (E) Immunoblotting of UVC-irradiated wild-type and $\triangle R I N G$ MEFs. (F) Caspase-3 was immunoprecipitated from MEFs $7 \mathrm{~h}$ after UVC or mock irradiation and immunoblotted with ubiquitin (left) or active caspase- 3 antibody (right). Cells were treated with $20 \mu \mathrm{M} \mathrm{MG-132}$ for the last $30 \mathrm{~min}$.

caspase- 3 and the cleaved large subunit to immunoprecipitate the caspase from mock- and UVC-irradiated cells, followed by immunoblotting with either an antibody against ubiquitin or the large subunit of caspase- 3 (Fig. 3F). A "smear" indicating polyubiquitination was detected when caspase- 3 was immunoprecipitated from irradiated wild-tye MEFs, but caspase-3 polyubiquitination was severely reduced in irradiated $\triangle R I N G$ MEFs. Collectively, these experiments suggest that XIAP E3ligase activity is required for ubiquitination of caspase- 3 in response to apoptotic stimuli, and that ubiquitination of caspase- 3 inhibits its protease activity. 


\section{Deletion of XIAP RING sensitizes MEFs to TNF- $\alpha$ apoptosis}

The TNF- $\alpha$ cytokine simultaneously engages apoptotic JNK and NF-кB survival signaling pathways in MEFs, and apoptosis only occurs when the NF- $\mathrm{B}$ pathway is inhibited by blocking protein synthesis (e.g., with cycloheximide [CHX]) or by inactivating specific components of the pathway (Beg and Baltimore 1996). Caspase-3 activity was greater in $\triangle R I N G$ cells when they were treated with CHX and TNF- $\alpha$ (Fig. 4A). Furthermore, treatment with TNF- $\alpha / \mathrm{CHX}$ accelerated different markers of apoptosis in $\triangle R I N G$ MEFs. Cleaved initiator caspase- 8 was detected by indirect immunofluorescence in greater percentages of $\triangle R I N G$ cells over time (Fig. 4B). Caspase-3 activation was accelerated (Fig. 4C), and $\triangle R I N G$ MEFs died faster than wild-type cells (Fig. 4D). We also examined MEFs from mice deficient for XIAP

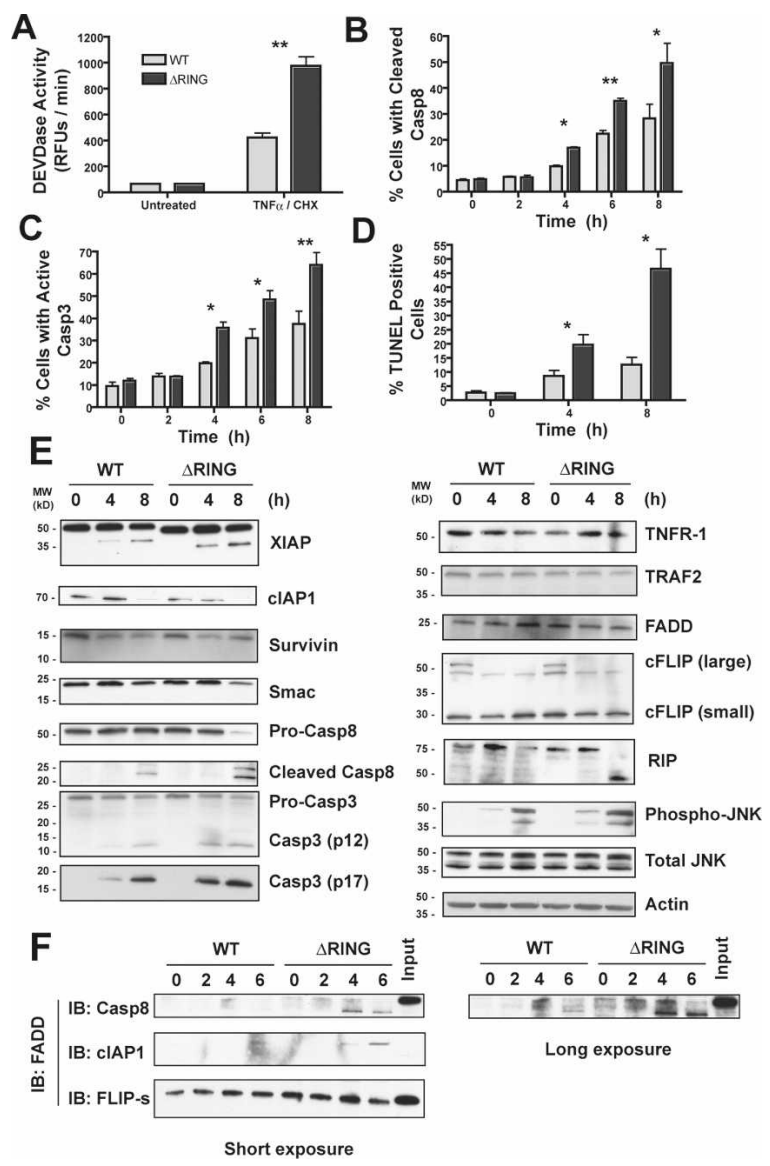

Figure 4. $\triangle R I N G$ MEFs are sensitized to TNF- $\alpha$ apoptosis. $(A)$ Caspase-3-like enzyme activity in bulk cellular lysates after $8 \mathrm{~h}$ of TNF- $\alpha / \mathrm{CHX}$ treatment. $(B)$ The percentages of cells with cleaved caspase- 8 were determined by indirect immunofluorescence over time. $(C)$ Caspase-3 activation measured by indirect immunofluorescence. $(D)$ Apoptosis measured by TUNEL staining. (E) Immunoblotting of TNF- $\alpha / C H X$-treated MEFs. $(F)$ The caspase- 8 activating complex was immunoprecipitated from TNF- $\alpha / C H X$-treated MEFs at the indicated times using a FADD antibody and immunoblotted with indicated antibodies. For $\left.A-D,\left(^{\star}\right) P<0.05 ;\left.\right|^{\star \star}\right) P<0.01$.
(Harlin et al. 2001) and found them to be equally sensitive to TNF- $\alpha / \mathrm{CHX}$-induced apoptosis (Supplemental Fig. 2A-D). Therefore, at least in this paradigm, deletion of the XIAP RING causes a similar sensitization toward apoptosis as a complete deletion of the XIAP gene. We also observed increased TNF- $\alpha$ apoptosis in $\triangle R I N G$ cells when the NF-кB pathway was inactivated specifically using RNAi against the RelA transcription factor (data not shown). This argues against nonspecific effects arising from general translational inhibition. The $\triangle R I N G$ mutation was not dominant in TNF- $\alpha / \mathrm{CHX}$ apoptosis: Complementing $\triangle R I N G$ cells with ectopic wild-type $X I A P$ restored caspase-3 activity to wild-type levels, while expression of $\triangle R I N G X I A P$ did not elevate caspase activity in wild-type cells (Supplemental Fig. 1E).

Both wild-type and $\triangle$ RING XIAP were cleaved during apoptosis, while cIAP1 and the BIR-containing protein Survivin were down-regulated similarly in both genotypes (Fig. 4E). The expression of Smac/DIABLO was similar in wild-type and $\triangle R I N G$ cells. Immunoblotting showed that enhanced caspase- 3 cleavage was evident after $4 \mathrm{~h}$ of treatment with TNF- $\alpha / \mathrm{CHX}$, and expression of the native form of caspase- 8 decreased after $8 \mathrm{~h}$ in $\triangle R I N G$ cells (Fig. 4E). The principal TNF receptor in MEFs, TNF-R1, was comparably expressed in cells of both genotypes, as were other key cytoplasmic components of the receptor complex like TRAF2, FADD, and c-FLIP, the large form of which was degraded during apoptosis (Fig. 4E). RIP kinase is a likely substrate for caspase-8 (Lin et al. 1999), and RIP was completely cleaved in $\triangle R I N G$ cells at a time ( $8 \mathrm{~h}$ ) when most of the cells were apoptotic. JNK activation (as assessed by phosphorylation) was essentially identical in wild-type and $\Delta R I N G$ cells, even at a time $(4 \mathrm{~h})$ when there were differences in death between cells of the two genotypes (Fig. $4 \mathrm{D}, \mathrm{E})$. Moreover, JNK activation is normal in TNF- $\alpha$ treated XIAP-null cells (Supplmental Fig. 2E; Harlin et al. 2001). These data suggest that the accelerated caspase activation in $\triangle R I N G$ and null cells is independent or downstream from signals that activate JNK. To further verify that apoptosis was genuinely accelerated in $\triangle R I N G$ cells, we used a FADD antibody to immunoprecipitate the complex that activates caspase- 8 in the cytoplasm after TNF- $\alpha$ treatment (Micheau and Tschopp 2003). Unprocessed and cleaved caspase- 8 were detected in complex with FADD after $4 \mathrm{~h}$ in $\triangle R I N G$ cells; this was evident after $6 \mathrm{~h}$ in wild-type cells upon longer exposure of the immunoblot (Fig. 4F). A higher molecular weight form of cIAP1 was recruited to the complex more quickly in $\triangle R I N G$ cells, while the short form of FLIP (FLIP-s) was bound at all times to FADD in cells of both genotypes. The increased susceptibility to death receptor apoptosis was not limited to TNF- $\alpha$. We saw hypersensitivity to death receptor apoptosis when RasV12/E1Atransformed $\triangle R I N G$ MEFs were treated with the death ligand TRAIL: Cleaved caspase- 3 and caspase- 8 were detected in a greater number of cells, caspase-3 enzyme activity was elevated, and cells died more readily (Supplemental Fig. 1A-D). These experiments illustrated the general sensitivity to apoptosis caused by members 
of the TNF- $\alpha$ superfamily of death ligands in cells with XIAP loss-of-function mutations, and they complement genetic arguments that XIAP nonredundantly inhibits TRAIL-induced apoptosis (Cummins et al. 2004).

The $\triangle R I N G$ mutation causes increased apoptosis and increased organismal survival in the Ep-Myc mouse lymphoma model

XIAP has been implicated in human tumorigenesis and lymphoproliferative diseases (Tamm et al. 2000; Nakagawa et al. 2005; Rigaud et al. 2006), and inhibiting XIAP and other IAPs with Smac/DIABLO-derived peptides (Fulda et al. 2002) or small molecule antagonists can reduce tumor xenografts in mice (Petersen et al. 2007). Although transgenic mice overexpressing human XIAP in the thymus have increased numbers of developing $\mathrm{T}$ cells and resistance to apoptosis (Conte et al. 2001), no published mouse models have shown a role for XIAP in tumorigenesis. Since genetic deletion of the XIAP RING domain appears to constitute a loss of function with respect to apoptosis inhibition in certain situations, we explored the effects of this mutation on an established mouse lymphoma and leukemia model. Transgenic mice develop lymphomas and lymphoblastic leukemias when $\mathrm{c}-\mathrm{Myc}$ is expressed in the B-cell compartment by the E $\mu$ immunoglobulin heavy chain enhancer (Adams et al. 1985). E $\mu-M y c$ transgenic mice provide a sensitized genetic background for studying the phenotypes of apoptosis gene mutations in vivo because misregulated c- $M y c$ expression is a potent inducer of apoptosis in the B-cell lineage (Strasser et al. 1990; Schmitt et al. 2002). By crossing the $\triangle R I N G$ allele onto the $\mathrm{E} \mu-\mathrm{Myc}$ background and following the survival of wild-type and $\triangle R I N G$ mice over time, we found that $\triangle R I N G$ mice showed improved survival on this sensitized background (median survival times: wild type, $127 \mathrm{~d}$; $\Delta R I N G$ : 246) (Fig. 5A). Peripheral white blood cell counts were consistently lower in $\triangle R I N G$ mice, while wild-type mice tended to show increases over time indicative of large blastic cell leukemias (Fig. 5B; data not shown). Proliferating B-cells in $\mathrm{E} \mu-M y c$ mice can be distinguished based on their increased size (Langdon et al. 1986; Sidman et al. 1993). We found decreased numbers of large proliferating $\mathrm{B}$ cells in the bone marrow of $\triangle R I N G \mathrm{E} \mu-M y c$ mice (Fig. $5 \mathrm{C}$ ). In order to examine whether this decrease could be due to increased death of B cells in $\triangle R I N G \mathrm{E \mu}-M y c$ mice, we compared the rate of apoptosis in $\mathrm{E} \mu-M y c \mathrm{~B}$ cells from wild-type and $\triangle R I N G$ mice. Removal of the XIAP RING led to elevated rates of apoptosis (Fig. 5D), consistent with the idea that increased death of $\mathrm{E} \mu-M y c \mathrm{~B}$ cells accounts for the observed decrease of proliferating B cells in the $\triangle R I N G$ mutant. Because apoptotic cells are rapidly cleared by phagocytes in situ, it is difficult to quantify rates of cell death in the bone marrow (Jacobsen et al. 1994). In order to circumvent this problem, we also isolated pure populations of B cells from the spleens of $\mathrm{E} \mu$ $M y c$ mice. Prior to isolation, the major cell populations in the spleens of wild-type, E $\mu-M y c$, and E $\mu-M y c \Delta R I N G$ mice were distributed similarly (data not shown). After
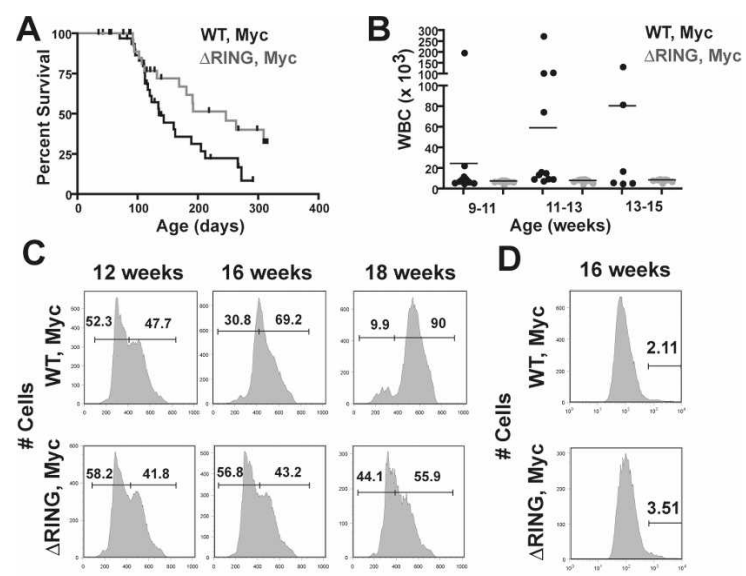

D
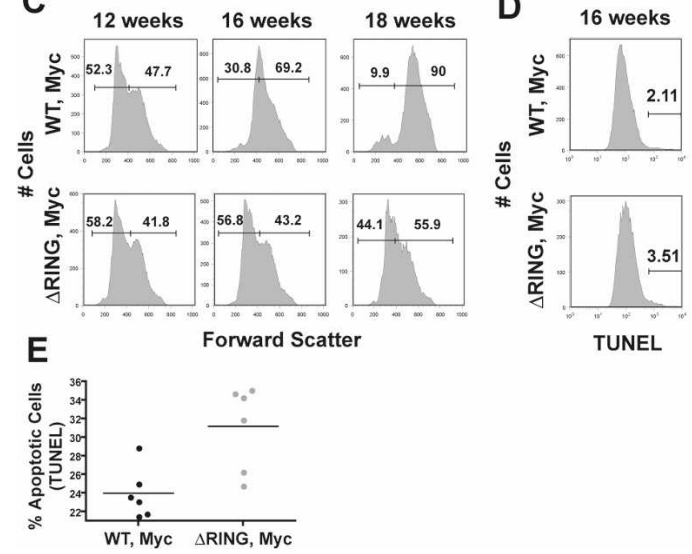

TUNEL

Figure 5. Impaired XIAP E3-ligase activity enhances organismal survival in the $\mathrm{E} \mu-M y c$ mouse lymphoma model and accelerates apoptosis of premalignant B cells. (A) Kaplan-Meier analysis of survival of wild-type $(n=34)$ and $\triangle R I N G$ mice $(n=32)$ on the E $\mu-M y c$ genetic background (log rank test: $P=0.037)$. Black ticks indicate the age of mice still alive at the time the graph was prepared, or used for an experiment. $(B)$ Peripheral white blood cell counts of mice of different ages. The black bars indicate mean counts. $(C)$ Histogram plots showing the fractions of large (proliferating) and small B220 $\mathrm{B}$ cells within the bone marrow of representative wild-type and $\triangle R I N G$ mice of different ages, as assessed by forward scatter. $(D)$ Deletion of the XIAP RING leads to increased apoptosis in large $\mathrm{B} 220^{+} \mathrm{B}$ cells from the bone marrow. Cells were isolated from the bone marrow as in $C$ and apoptosis was assessed by TUNEL staining. (E) Deletion of the XIAP RING sensitizes E $\mu-M y c$ B cells to apoptosis. B cells were isolated from the spleens of E $\mu$ Myc mice and were cultured without serum for $3.5 \mathrm{~h}$; at this point apoptosis was assessed by TUNEL.

purifying $\mathrm{B}$ cells, the isolated cells were nearly pure populations of early B cells $\left(>95 \% \mathrm{~B}^{2} 20^{+}, \mathrm{CD}^{2} 3^{-}, \mathrm{IgM}^{-}\right)$ as assessed by flow cytometry. We deprived the purified $\mathrm{E} \mu-M y c$ B cells of serum because B cells that misexpress Myc are strongly sensitized to apoptosis caused by growth factor withdrawal (Milner et al. 1993; Cherney et al. 1994). B cells isolated from $\mathrm{E} \mu-M y c \Delta R I N G$ mice showed significantly enhanced apoptosis $(P<0.01$ by two-tailed Student's $t$-test) (Fig. 5E). These results suggest that impaired XIAP E3 ubiquitin-ligase activity inhibits tumor formation and prolongs organismal survial by sensitizing premalignant $B$ cells to apoptosis.

\section{Discussion}

Previous efforts to study the regulation of apoptosis by XIAP have largely focused on how BIR domains bind and inhibit caspases, often by relying on overexpression in cancer cell lines and on the biochemical and structural 
analyses of isolated domains (Hunter et al. 2007). These approaches have offered valuable insights into the molecular mechanisms by which XIAP may regulate caspases, and they also guided the design of small-molecule therapeutics that disrupt BIR/caspase complexes to promote apoptosis in tumors (Carter et al. 2005; Petersen et al. 2007; Varfolomeev et al. 2007; Vince et al. 2007). However, because no significant phenotypes for XIAPnull mice were previously reported, the physiological function of this protein in mammalian apoptosis has remained unclear. Here we show that XIAP function is required for negative regulation of caspases and apoptosis in certain murine cell types in situ, and that inactivation of the E3-ligase activity of XIAP inhibits tumor formation and prolongs survival in a mouse model of lymphoma. Much of the current study focuses on the importance of the XIAP RING domain, which bestows E3 ubiqutin-ligase activity on XIAP. However, we also investigated XIAP-null mice (Harlin et al. 2001) in several paradigms and obtained results virtually identical to the ones seen for XIAP $\triangle R I N G$ (Supplemental Fig. 2A; data not shown). One surprising conclusion from the current study is that deletion of the XIAP RING causes increased caspase activity and sensitivity toward TNF- $\alpha$ apoptosis comparable with complete inactivation of XIAP. This is surprising because the prevailing view, based on biochemical and structural biology data, has been that IAPs inhibit caspases via direct binding through their BIR domain (Salvesen and Duckett 2002; Eckelman and Salvesen 2006). Furthermore, a truncated XIAP protein containing only the BIR domains (BIR $1+2+3$ ) inhibits caspases in vitro and apoptosis upon overexpression in cultured cells comparably with the full-length protein (Takahashi et al. 1998; Silke et al. 2002). Additionally, the different BIR domains fold correctly, bind caspases, and account for virtually all inhibition of caspases by XIAP in vitro when expressed individually (Takahashi et al. 1998; Sun et al. 1999, 2000; Chai et al. 2001; Riedl et al. 2001; Shiozaki et al. 2003; Scott et al. 2005). Therefore, based on these studies, the increased amounts of "BIR-only" XIAP protein in our XIAP $\triangle R I N G$ mice would have been expected to cause reduced caspase activity and apoptosis, and not increased activity as we found. In addition, the $\triangle R I N G$ mutation does not appear to exert a dominant effect. Although we were not able to directly study heterozygous combinations of wild-type and $\triangle R I N G$ alleles because of $\mathrm{X}$-chromosome inactivation, we found that elevated caspase activity was rescued in $\triangle R I N G$ cells after stably reintroducing a full-length XIAP construct containing the RING (Supplemental Fig. 1C). Finally, expression of a $\triangle R I N G$ XIAP construct did not sensitize wild-type cells to TNF- $\alpha / \mathrm{CHX}$ apoptosis, as might have been expected from a dominant-negative mutant.

Our results establish an anti-apoptotic function of the XIAP RING domain for certain cell types in vivo. However, it is important to note that different cell types displayed different requirements for XIAP function. For example, consistent with previous studies, caspase activity and apoptosis of thymocytes was not significantly af- fected by inactivation of XIAP or loss of XIAP RING function (Fig. 2; Harlin et al. 2001). In addition, the sensitivity to death receptor apoptosis was not common to all $\Delta$ RING cell types: Hepatocellular apoptosis occurred normally in vivo following intravenous administration of agonistic Fas antibody, or TNF- $\alpha$ together with the liver-selective transcriptional inhibitor GalN (Supplemental Fig. 2F; data not shown). A key difference between death receptor apoptosis in MEFs and hepatocytes is the obligate requirement for mitochondrial factors in hepatocyte apoptosis (Yin et al. 1999), and it is possible that one of these proteins modulates the effect of the $\triangle R I N G$ mutation. In any case, the present work illustrates the difficulties in drawing generalized conclusions regarding physiological function from in vitro studies and limited analysis of select cell types.

How RING ubiquitin-ligase activity regulates apoptosis in mammalian cells remains largely unknown. In Drosophila, the E3 ubiquitin-ligase activity of Diap1 is required for ubiquitin-mediated degradation of the caspase Dronc and to prevent unwanted apoptosis (Wilson et al. 2002; Ryoo et al. 2004; Steller 2008). In addition, Reaper family IAP antagonists can stimulate Diap1 autoubiquitination during apoptosis that leads to Diap1 degradation, and a RING mutant is stable in the presence of Reaper (Ryoo et al. 2002). Inactivation of the mouse XIAP RING by gene targeting revealed parallels with fruit fly Diap1 RING functions, and differences as well. While Diap1 RING mutants die as advanced embryos, $\triangle R I N G$ mice are viable on mixed and congenic C57BL/6 backgrounds. This may reflect different regulatory strategies between insects and mammals, or alternatively greater functional redundancy of IAP family members in mammals (Steller 2008). Nonetheless, like in Drosophila, XIAP RING function influences caspase activity and ubiquitination in embryonic cells: Caspase-3 enzyme activity was elevated in $\triangle R I N G$ cells in response to diverse apoptotic stimuli and irradiated MEFs were defective in caspase subunit ubiquitination (Fig. 3). However, caspase subunit abundance was not dramatically altered in apoptotic $\triangle R I N G$ cells, indicating that polyubiquitination may not lead to degradation of caspases. In principle the ubiquitination of active caspase- 3 by a functional XIAP RING could impair the enzymatic activity of a caspase or its ability to form functional dimers, although $\triangle R I N G$ cells could tolerate higher caspase activity without increased death when cells were killed through the mitochondrial pathway of apoptosis (Fig. 3C).

IAPs have diverse regulatory roles in death receptor signaling pathways (Li et al. 2004; Varfolomeev et al. 2007; Vince et al. 2007). cIAP1 is a key negative regulator of an NF-кB-dependent, autocrine TNF- $\alpha$ apoptosis program that is revealed in the presence of an IAP antagonist, and immortalized cIAP1-null cells are killed by TNF- $\alpha$ alone (Vince et al. 2007). The observation that $X I A P$-null cancer cells are highly susceptible to TRAIL offered the first genetic evidence that XIAP may be a nonredundant regulator of death receptor apoptosis (Cummins et al. 2004). We established a clear role for the 
XIAP RING in negatively regulating TNF- $\alpha / \mathrm{CHX}$ and TRAIL apoptosis. This effect is probably independent of signals that activate JNK, since the phosphorylation events that activate JNK occurred normally in $\triangle R I N G$ cells (Fig. 4E) and XIAP-null MEFs (Supplemental Fig. 2E; Harlin et al. 2001). Moreover, the JNK phosphorylation state remained transient in $\triangle R I N G$ cells when TNF- $\alpha$ was added alone in the presence of intact NF- $к B$ signaling (data not shown). TNF- $\alpha / \mathrm{CHX}$ apoptosis was genuinely accelerated, because the caspase- 8 activating complex was assembled more quickly in mutant MEFs (Fig. 4F). RING ubiquitin-ligases usually function to regulate the abundance of their binding partners, but the differential sensitivity between wild-type and $\triangle R I N G$ cells was not obvious from the protein expression levels of key components in the TNF effector pathways.

Although $\triangle R I N G$ mice appeared as healthy as wildtype littermates, we found an anti-apoptotic role for RING function after crossing mutant mice onto the $\mathrm{E} \mu$ Myc transgenic background. The importance of apoptosis in modulating cancer progression in $\mathrm{E \mu}-\mathrm{Myc}$ mice is evident from animals carrying mutations in cell death genes (Strasser et al. 1990; Schmitt et al. 2002). We found small but reproducible increases in apoptosis in the population of proliferating, premalignant $\triangle R I N G$ B cells, and a general decrease in their relative abundance (Fig. $5 \mathrm{D}, \mathrm{E})$. Our genetic evidence supports the long-standing notion that XIAP antagonism can lead to the death of cancer cells (Hunter et al. 2007). Further support for an anti-apoptotic role for XIAP in lymphoid disorders comes from a positional cloning effort that identified $X I A P$ deficiency as a genetic basis for the human $\mathrm{X}$-linked lymphoproliferative syndrome (Rigaud et al. 2006). Lymphocytes in afflicted patients are sensitized to TRAIL and Fas death receptor apoptosis, and natural killer T lymphocytes are depleted. Collectively, our data demonstrate that XIAP, and RING function in particular, play a far greater role in regulating apoptosis in vivo than was previously recognized.

\section{Materials and methods}

\section{Engineering XIAP $\triangle$ RING knock-in mice}

We used homologous recombination in mouse ES cells (E14 line, 129/Ola strain) to replace the first two codons of the XIAP RING (C449 and K450) with tandem stop codons followed by a diagnostic SacI restriction site. This mutation was designed to truncate the RING and the 13-amino-acid sequence between the RING and the C terminus. An X-chromosome BAC (RPCI 23 207E14) served as the PCR template for the targeting vector. We positioned a removable positive selection cassette (PGKneomycin phosphotransferase) flanked by FRT sites in a neighboring intron, and a negative selection cassette (PGK-diphtheria toxin A) located outside of the homology region, to enrich for positively targeted clones. Positive clones were identified by Southern blotting of SacI-digested genomic DNA with an external probe and confirmed by direct sequencing. Three independently targeted clones were injected into C57BL/6 blastocysts and implanted into pseudopregnant females. Two clones (\#49 and \#129) yielded chimeric mice and transmitted the mutant allele through the germline. Mice from both founder lines gave identical results and line \#129 was chosen arbitrarily to found the colony. The neomycin cassette was removed in vivo by crossing $\triangle R I N G$ mice with "FLPeR" mice expressing the FLPe recombinase ubiquitously (Farley et al. 2000). Excision of the neomycin cassette was verified by Southern blotting of ApaLIdigested genomic DNA with the same probe. Mice were also genotyped by PCR primers (forward primer sequence, 5'TAAAGCCTTTACCTTCTTCTCTATTTCC-3'; reverse primer sequence, 5' -TGGGACAGGTAGGATTTAGTGCTTCG-3'; annealing temperature of $55^{\circ} \mathrm{C}$ ) that flanked the site of the residual intronic FRT site and gave a larger PCR product from the $\triangle R I N G$ allele. Initial experiments conducted on a mixed $129 / \mathrm{Ola} / \mathrm{C} 57 \mathrm{BL} / 6$ genetic background were confirmed on a C57BL/6 congenic background after backcrossing mice more than 10 generations. Animals were housed in a specific pathogen-free environment, and the institutional animal care and use committee at the Rockefeller University approved all experiments.

\section{Primary cell culture}

Hemizygous $\triangle R I N G$ ES cells and the isogenic wild-type E14 parental line used for gene targeting were cultured on gelatinized dishes without feeder layers in the presence of $10 \mathrm{ng} / \mathrm{mL}$ leukemia inhibitory factor (Chemicon). The intronic neomycin cassette was removed by expressing the FLPe recombinase transiently with the mouse ES cell Nucleofection kit (program A-23; Amaxa) and screening individual colonies by Southern blotting of ApaLI-digested DNA. MEFs were isolated from 12.5-d embryos and used through the fifth passage. We obtained polyclonal pools of transformed fibroblasts by infecting primary cells with a bicistronic $\mathrm{pBabe}$ RasV12/E1A vector packaged into an ecotropic retrovirus by Phoenix cells. ES cells and MEFs were cultured in DMEM with $15 \%$ fetal bovine serum. Single-cell thymocyte suspensions were prepared from 4- to 6-wk-old littermate mice and cultured in RPMI-1640 medium with $10 \%$ fetal bovine serum.

\section{Apoptosis experiments}

ES cells were treated with $100 \mu \mathrm{M}$ etoposide or $1 \mu \mathrm{M}$ staurosporine for $10 \mathrm{~h}$. Primary MEFs were treated with $100 \mathrm{ng} / \mathrm{mL}$ TNF- $\alpha$ and $1 \mu \mathrm{g} / \mathrm{mL}$ CHX or irradiated with $120 \mathrm{~mJ} / \mathrm{cm}^{2}$ UVC. Transformed MEFs were treated with TNF- $\alpha / \mathrm{CHX}$ for $3.5 \mathrm{~h}, 100$ $\mu \mathrm{M}$ etoposide or $60 \mathrm{~mJ} / \mathrm{cm}^{2} \mathrm{UVC}$ for $5 \mathrm{~h}$, or $50 \mathrm{ng} / \mathrm{mL}$ TRAIL for $10 \mathrm{~h}$. Thymocytes were treated with $10 \mu \mathrm{M}$ etoposide, $1 \mu \mathrm{M}$ dexamethasone, or left untreated for $8 \mathrm{~h}$. Trypsinized single-cell ES and MEF suspensions were collected with detached dead cells, fixed in $2 \%$ paraformaldehyde, and assayed for caspase- 3 or caspase- 8 activation by indirect immunofluorescence with cleaved caspase antibodies (caspase-3: 1:200 dilution, Cell Signaling, 9661; caspase-8: 1:50 dilution, Cell Signaling, 18C8), or labeled by TUNEL according to the manufacturer's instructions (MBL International). Caspase-3 activation was measured in thymocytes by incubating unfixed cells with the FAM-DEVD-fmk FLICA affinity tag following the manufacturer's instructions (Immunochemistry Technologies), and TUNEL was assayed in fixed thymocytes as with embryonic cells. The percentages of cleaved caspase- and TUNEL-positive cells were determined by flow cytometry using FACSCalibur (BD Biosciences). Bulk caspase-3-like activity was calculated by normalizing lysates for total protein content using the Bradford reagent (Bio-Rad), then measuring the linear rate of cleavage of a fluorescent Z-DEVDR110 substrate using the EnzChek Caspase-3 Assay Kit \#2 (In- 
vitrogen) and a SpectraMax M2 multiwell plate reader (Molecular Devices).

\section{Immunoblotting and immunoprecipitation}

Cells were homogenized in lysis buffer $(20 \mathrm{mM}$ Tris at $\mathrm{pH} 7.5$, $150 \mathrm{mM} \mathrm{NaCl}, 1 \mathrm{mM}$ EDTA, $1 \mathrm{mM}$ EGTA, $1 \%$ Triton X-100) supplemented with protease inhibitors (1 mM PMSF, $2 \mu \mathrm{g} / \mathrm{mL}$ leupeptin, $100 \mathrm{nM}$ benzamidine, $1 \mu \mathrm{M}$ pepstatin A). Lysates were incubated on ice for $30 \mathrm{~min}$ and clarified by centrifugation at $14,000 \mathrm{RPM}$ at $4^{\circ} \mathrm{C}$ before normalizing protein concentrations using the Bradford assay. Protein samples were resolved on SDS-PAGE Ready Gels (Bio-Rad) and electroblotted on Immobilon-P membranes (Millipore). Membranes were blocked for $1 \mathrm{~h}$ at room temperature in blocking buffer $15 \%[\mathrm{w} / \mathrm{v}]$ nonfat milk in $0.5 \%$ [v/v] Tween 20/PBS) and incubated overnight at $4^{\circ} \mathrm{C}$ with antibodies dissolved in blocking buffer. Membranes were washed with $0.5 \%$ Tween $20 /$ PBS wash solution, incubated for $30 \mathrm{~min}$ at room temperature with appropriate secondary antibodies conjugated to horseradish peroxidase, and dissolved in blocking buffer before washing again. Signals were detected with the West Femto chemiluminescent kit (Pierce Biotechnology).

To immunoprecipitate caspase-3, MEFs were irradiated with $120 \mathrm{~mJ} / \mathrm{cm}^{2} \mathrm{UVC}$ and harvested after $7 \mathrm{~h} ; 20 \mu \mathrm{M}$ MG-132 was added to cells $30 \mathrm{~min}$ before collection. Cell pellets were lysed in hot $1 \%(\mathrm{w} / \mathrm{v})$ SDS to dissociate protein/protein interactions, then diluted 10 -fold in $1 \%$ Triton X-100 lysis buffer. Lysates were clarified by centrifugation and normalized for total protein content before rotating overnight at $4{ }^{\circ} \mathrm{C}$ with a caspase- 3 antibody (1:100; Cell Signaling, 8G10 rabbit monoclonal). Immunocomplexes were collected with $25 \mu \mathrm{L}$ of protein A-magnetic beads (New England Biolabs) by rotating for $2 \mathrm{~h}$ at $4^{\circ} \mathrm{C}$. Beads were washed three times in cold PBS and eluted in SDS-PAGE sample buffer (New England Biolabs) for $5 \mathrm{~min}$ at $95^{\circ} \mathrm{C}$ before immunoblotting. To immunoprecipitate caspase- 8 complexes, MEFs were treated with TNF- $\alpha / \mathrm{CHX}$ and harvested by scraping detached and adherent cells from two $10-\mathrm{cm}$ plates per treatment. Cell lysates were prepared in lysis buffer $(20 \mathrm{mM}$ Tris at pH 7.5, 150 mM NaCl, $0.2 \%$ Nonidet P40, 10\% glycerol) supplemented with protease inhibitors, and then snap-frozen in liquid nitrogen. Lysates were thawed, clarified by centrifugation and normalized for total protein content (600 $\mu$ g per sample) before rotating overnight with a FADD antibody $(2 \mu \mathrm{g}$; Santa Cruz Biotechnologies, M-19 goat polyclonal). Immunocomplexes were collected as described above, except using protein G-magnetic beads (New England Biolabs).

\section{Eu-Myc experiments}

$\triangle R I N G$ mice were backcrossed to C57BL/6 mice for at least six generations before mating with $\mathrm{C} 57 \mathrm{BL} / 6 \mathrm{E} \mu-M y c$ mice obtained from Jackson Laboratory [strain B6.Cg-Tg(IghMyc)22Bri/J]. Cohorts of mice were monitored for lymphoma-free survival over time before generating a Kaplan-Meier survival curve. Peripheral blood was sampled periodically by retro-orbital eye bleeds and analyzed by the Laboratory of Comparative Pathology at Memorial Sloan-Kettering Cancer Center. For bone marrow analysis, cell suspensions were flushed from femurs and tibias, treated with erythrocyte lysis buffer ( 9 vol of $150 \mathrm{mM} \mathrm{NH}_{4} \mathrm{Cl}, 1$ vol of $130 \mathrm{mM}$ Tris-Cl at $\mathrm{pH} 7.65$ ), and stained with B220-APC (1:50; BD Pharmingen) for $20 \mathrm{~min}$ on ice to label B cells. Cells were fixed in $3 \%$ paraformaldehyde for $15 \mathrm{~min}$ at room temperature, permeabilized in $2 \%$ Triton X-100/PBS for 15 min at room temperature, then assayed by TUNEL. Apoptosis was measured in proliferating $\mathrm{B}$ cells by gating large-scattering
$\mathrm{B} 220^{+}$cells. B cells were purified from $\mathrm{E} \mu-\mathrm{Myc}$ spleens by magnetically depleting non-B cells (Miltenyi Biotec); sample purity was verified by flow cytometry. Cells were cultured without serum in B-cell medium (50\% Iscove's MEM, 50\% DMEM, 100 $\mathrm{U} / \mathrm{mL}$ penicillin, $100 \mu \mathrm{g} / \mathrm{mL}$ streptomycin, $4 \mathrm{mM}$ l-glutamine, $25 \mu \mathrm{M} 2$-mercaptoethanol) for $3.5 \mathrm{~h}$ before performing TUNEL.

\section{Reagents and antibodies}

Etoposide, staurosporine, dexamethasone, MG132, and CHX were from Sigma-Aldrich; murine TNF- $\alpha$ was from Peprotech; SuperKiller TRAIL and zVAD-fmk were from Alexis. Antibodies and dilutions used for immunoblotting were XIAP (1:1000; $\mathrm{BD}$, clone 28), cIAP1 (1:2000; R\&D Systems, AF818), survivin (1:2000; R\&D Systems, AF886), Smac/DIABLO (1:2000; BD, clone 56), caspase-3 (p32/p17; 1:1000; Cell Signaling, 8G10), cleaved caspase-3 (p17; 1:1000; Cell Signaling, 9661), caspase-9 (1:1000; Cell Signaling, 9504), caspase-8 (1:1000; Cell Signaling, 4927), phospho-JNK (1:1000; Cell Signaling, 9251), total JNK (1:2000; Santa Cruz Biotechnologies, sc-571), TRAF2 (1:1000; Cell Signaling, 4712), TNF-R1 (1:500; Santa Cruz Biotechnologies, H-5), FLIP (1:1000; Cell Signaling, 3210), FADD (1:500; Santa Cruz Biotechnologies, M-19), ubiquitin (1:500; Sigma, U5379), RIP (1:1000; Cell Signaling, 4926), and actin (1:20,000; Sigma, AC15). Caspase-3 (p32/p12) and caspase-7 antibodies were a gift from Joe Rodriguez.

\section{Statistical analysis}

All bar graphs are shown with the mean and standard error of at least three independent experiments, and $P$-values are from paired two-tailed Student's $t$-tests.

\section{Acknowledgments}

We thank Holger Kissel for helpful discussions, Donal O'Carroll for advice on culturing ES cells and supplying FLPeR mice, and Samara Brown for technical assistance and mouse genotyping. We also thank the Rockefeller University Gene Targeting and Transgenic Services for generating mice. A.J.S. is a recipient of a Howard Hughes Medical Institute Predoctoral Fellowship, M.G-F. is a recipient of a Caja Madrid Foundation Post-Graduate Fellowship, and H.S. is an Investigator with the Howard Hughes Medical Institute. Part of this work was supported by NIH grant RO1GM60124 to H.S.

\section{References}

Adams, J.M. and Cory, S. 2007. Bcl-2-regulated apoptosis: Mechanism and therapeutic potential. Curr. Opin. Immunol. 19: 488-496.

Adams, J.M., Harris, A.W., Pinkert, C.A., Corcoran, L.M., Alexander, W.S., Cory, S., Palmiter, R.D., and Brinster, R.L. 1985. The c-myc oncogene driven by immunoglobulin enhancers induces lymphoid malignancy in transgenic mice. Nature 318: 533-538.

Beg, A.A. and Baltimore, D. 1996. An essential role for NF-кB in preventing TNF- $\alpha$-induced cell death. Science 274: 782-784.

Bergmann, A., Agapite, J., and Steller, H. 1998. Mechanisms and control of programmed cell death in invertebrates. Oncogene 17: 3215-3223.

Carter, B.Z., Gronda, M., Wang, Z., Welsh, K., Pinilla, C., Andreeff, M., Schober, W.D., Nefzi, A., Pond, G.R., Mawji, I.A., et al. 2005. Small-molecule XIAP inhibitors derepress downstream effector caspases and induce apoptosis of acute my- 
eloid leukemia cells. Blood 105: 4043-4050.

Cashio, P., Lee, T.V., and Bergmann, A. 2005. Genetic control of programmed cell death in Drosophila melanogaster. Semin. Cell Dev. Biol. 16: 225-235.

Chai, J., Shiozaki, E., Srinivasula, S.M., Wu, Q., Datta, P., Alnemri, E.S., and Shi, Y. 2001. Structural basis of caspase-7 inhibition by XIAP. Cell 104: 769-780.

Chen, P., Nordstrom, W., Gish, B., and Abrams, J.M. 1996. grim, a novel cell death gene in Drosophila. Genes \& Dev. 10: 1773-1782.

Cherney, B.W., Bhatia, K., and Tosato, G. 1994. A role for deregulated c-Myc expression in apoptosis of Epstein-Barr virus-immortalized B cells. Proc. Natl. Acad. Sci. 91: 1296712971.

Conte, D., Liston, P., Wong, J.W., Wright, K.E., and Korneluk, R.G. 2001. Thymocyte-targeted overexpression of xiap transgene disrupts $\mathrm{T}$ lymphoid apoptosis and maturation. Proc. Natl. Acad. Sci. 98: 5049-5054.

Conte, D., Holcik, M., Lefebvre, C.A., Lacasse, E., Picketts, D.J., Wright, K.E., and Korneluk, R.G. 2006. Inhibitor of apoptosis protein cIAP2 is essential for lipopolysaccharide-induced macrophage survival. Mol. Cell. Biol. 26: 699-708.

Conze, D.B., Albert, L., Ferrick, D.A., Goeddel, D.V., Yeh, W.C., Mak, T., and Ashwell, J.D. 2005. Posttranscriptional downregulation of c-IAP2 by the ubiquitin protein ligase c-IAP1 in vivo. Mol. Cell. Biol. 25: 3348-3356.

Cummins, J.M., Kohli, M., Rago, C., Kinzler, K.W., Vogelstein, B., and Bunz, F. 2004. X-linked inhibitor of apoptosis protein (XIAP) is a nonredundant modulator of tumor necrosis factor-related apoptosis-inducing ligand (TRAIL)-mediated apoptosis in human cancer cells. Cancer Res. 64: 3006-3008.

Degenhardt, K. and White, E. 2006. A mouse model system to genetically dissect the molecular mechanisms regulating tumorigenesis. Clin. Cancer Res. 12: 5298-5304.

Deveraux, Q.L., Roy, N., Stennicke, H.R., Van Arsdale, T., Zhou, Q., Srinivasula, S.M., Alnemri, E.S., Salvesen, G.S., and Reed, J.C. 1998. IAPs block apoptotic events induced by caspase- 8 and cytochrome $\mathrm{c}$ by direct inhibition of distinct caspases. EMBO J. 17: 2215-2223.

Eckelman, B.P. and Salvesen, G.S. 2006. The human anti-apoptotic proteins cIAP1 and cIAP2 bind but do not inhibit caspases. J. Biol. Chem. 281: 3254-3260.

Farley, F.W., Soriano, P., Steffen, L.S., and Dymecki, S.M. 2000. Widespread recombinase expression using FLPeR (flipper) mice. Genesis 28: 106-110.

Fulda, S., Wick, W., Weller, M., and Debatin, K.M. 2002. Smac agonists sensitize for Apo2L/TRAIL- or anticancer drug-induced apoptosis and induce regression of malignant glioma in vivo. Nat. Med. 8: 808-815.

Gottfried, Y., Rotem, A., Lotan, R., Steller, H., and Larisch, S. 2004. The mitochondrial ARTS protein promotes apoptosis through targeting XIAP. EMBO J. 23: 1627-1635.

Goyal, L., McCall, K., Agapite, J., Hartwieg, E., and Steller, H. 2000. Induction of apoptosis by Drosophila reaper, hid and grim through inhibition of IAP function. EMBO $J$. 19: 589597.

Grether, M.E., Abrams, J.M., Agapite, J., White, K., and Steller, H. 1995. The head involution defective gene of Drosophila melanogaster functions in programmed cell death. Genes \& Dev. 9: 1694-1708.

Grimm, L.M., Goldberg, A.L., Poirier, G.G., Schwartz, L.M., and Osborne, B.A. 1996. Proteasomes play an essential role in thymocyte apoptosis. EMBO J. 15: 3835-3844.

Hanahan, D. and Weinberg, R.A. 2000. The hallmarks of cancer. Cell 100: $57-70$.

Harlin, H., Reffey, S.B., Duckett, C.S., Lindsten, T., and Thomp- son, C.B. 2001. Characterization of XIAP-deficient mice. Mol. Cell. Biol. 21: 3604-3608.

Harrington, E.A., Fanidi, A., and Evan, G.I. 1994. Oncogenes and cell death. Curr. Opin. Genet. Dev. 4: 120-129.

Hunter, A.M., LaCasse, E.C., and Korneluk, R.G. 2007. The inhibitors of apoptosis (IAPs) as cancer targets. Apoptosis 12: 1543-1568.

Jacobsen, K.A., Prasad, V.S., Sidman, C.L., and Osmond, D.G. 1994. Apoptosis and macrophage-mediated deletion of precursor B cells in the bone marrow of E $\mu-m y c$ transgenic mice. Blood 84: 2784-2794.

Jacobson, M.D., Weil, M., and Raff, M.C. 1997. Programmed cell death in animal development. Cell 88: 347-354.

Joazeiro, C.A. and Weissman, A.M. 2000. RING finger proteins: Mediators of ubiquitin ligase activity. Cell 102: 549-552.

Jones, J.M., Datta, P., Srinivasula, S.M., Ji, W., Gupta, S., Zhang, Z., Davies, E., Hajnoczky, G., Saunders, T.L., Van Keuren, M.L., et al. 2003. Loss of Omi mitochondrial protease activity causes the neuromuscular disorder of mnd2 mutant mice. Nature 425: 721-727.

Kornbluth, S. and White, K. 2005. Apoptosis in Drosophila: Neither fish nor fowl (nor man, nor worm). J. Cell Sci. 118: 1779-1787.

Langdon, W.Y., Harris, A.W., Cory, S., and Adams, J.M. 1986. The c-myc oncogene perturbs B lymphocyte development in E-mu-myc transgenic mice. Cell 47: 11-18.

Larisch, S., Yi, Y., Lotan, R., Kerner, H., Eimerl, S., Tony Parks, W., Gottfried, Y., Birkey Reffey, S., de Caestecker, M.P., Danielpour, D., et al. 2000. A novel mitochondrial septinlike protein, ARTS, mediates apoptosis dependent on its Ploop motif. Nat. Cell Biol. 2: 915-921.

Li, L., Thomas, R.M., Suzuki, H., De Brabander, J.K., Wang, X., and Harran, P.G. 2004. A small molecule Smac mimic potentiates TRAIL- and TNF $\alpha$-mediated cell death. Science 305: 1471-1474

Lin, Y., Devin, A., Rodriguez, Y., and Liu, Z.G. 1999. Cleavage of the death domain kinase RIP by caspase- 8 prompts TNFinduced apoptosis. Genes \& Dev. 13: 2514-2526.

Lisi, S., Mazzon, I., and White, K. 2000. Diverse domains of THREAD/DIAP1 are required to inhibit apoptosis induced by REAPER and HID in Drosophila. Genetics 154: 669-678.

Martins, L.M., Morrison, A., Klupsch, K., Fedele, V., Moisoi, N., Teismann, P., Abuin, A., Grau, E., Geppert, M., Livi, G.P., et al. 2004. Neuroprotective role of the Reaper-related serine protease HtrA2/Omi revealed by targeted deletion in mice. Mol. Cell. Biol. 24: 9848-9862.

Micheau, O. and Tschopp, J. 2003. Induction of TNF receptor I-mediated apoptosis via two sequential signaling complexes. Cell 114: 181-190.

Miller, L.K. 1999. An exegesis of IAPs: Salvation and surprises from BIR motifs. Trends Cell Biol. 9: 323-328.

Milner, A.E., Grand, R.J., Waters, C.M., and Gregory, C.D. 1993. Apoptosis in Burkitt lymphoma cells is driven by c-myc. Oncogene 8: 3385-3391.

Nakagawa, Y., Hasegawa, M., Kurata, M., Yamamoto, K., Abe, S., Inoue, M., Takemura, T., Hirokawa, K., Suzuki, K., and Kitagawa, M. 2005. Expression of IAP-family proteins in adult acute mixed lineage leukemia (AMLL). Am. J. Hematol. 78: 173-180.

Okada, H., Suh, W.K., Jin, J., Woo, M., Du, C., Elia, A., Duncan, G.S., Wakeham, A., Itie, A., Lowe, S.W., et al. 2002. Generation and characterization of Smac/DIABLO-deficient mice. Mol. Cell. Biol. 22: 3509-3517.

Olayioye, M.A., Kaufmann, H., Pakusch, M., Vaux, D.L., Lindeman, G.J., and Visvader, J.E. 2005. XIAP-deficiency leads to delayed lobuloalveolar development in the mammary 
gland. Cell Death Differ. 12: 87-90.

Petersen, S.L., Wang, L., Yalcin-Chin, A., Li, L., Peyton, M., Minna, J., Harran, P., and Wang, X. 2007. Autocrine TNFo signaling renders human cancer cells susceptible to Smacmimetic-induced apoptosis. Cancer Cell 12: 445-456.

Potts, P.R., Singh, S., Knezek, M., Thompson, C.B., and Deshmukh, M. 2003. Critical function of endogenous XIAP in regulating caspase activation during sympathetic neuronal apoptosis. J. Cell Biol. 163: 789-799.

Reed, J.C. 2003. Apoptosis-targeted therapies for cancer. Cancer Cell 3: 17-22.

Riedl, S.J., Renatus, M., Schwarzenbacher, R., Zhou, Q., Sun, C., Fesik, S.W., Liddington, R.C., and Salvesen, G.S. 2001. Structural basis for the inhibition of caspase-3 by XIAP. Cell 104: 791-800

Rigaud, S., Fondaneche, M.C., Lambert, N., Pasquier, B., Mateo, V., Soulas, P., Galicier, L., Le Deist, F., Rieux-Laucat, F., Revy, P., et al. 2006. XIAP deficiency in humans causes an X-linked lymphoproliferative syndrome. Nature 444: 110114.

Ryoo, H.D., Bergmann, A., Gonen, H., Ciechanover, A., and Steller, H. 2002. Regulation of Drosophila IAP1 degradation and apoptosis by reaper and ubcD1. Nat. Cell Biol. 4: 432438.

Ryoo, H.D., Gorenc, T., and Steller, H. 2004. Apoptotic cells can induce compensatory cell proliferation through the JNK and the Wingless signaling pathways. Dev. Cell 7: 491-501.

Salvesen, G.S. and Abrams, J.M. 2004. Caspase activationStepping on the gas or releasing the brakes? Lessons from humans and flies. Oncogene 23: 2774-2784.

Salvesen, G.S. and Duckett, C.S. 2002. IAP proteins: Blocking the road to death's door. Nat. Rev. Mol. Cell Biol. 3: 401-410.

Schmitt, C.A., Fridman, J.S., Yang, M., Baranov, E., Hoffman, R.M., and Lowe, S.W. 2002. Dissecting p53 tumor suppressor functions in vivo. Cancer Cell 1: 289-298.

Scott, F.L., Denault, J.B., Riedl, S.J., Shin, H., Renatus, M., and Salvesen, G.S. 2005. XIAP inhibits caspase- 3 and -7 using two binding sites: Evolutionarily conserved mechanism of IAPs. EMBO J. 24: 645-655.

Shi, Y. 2002. A conserved tetrapeptide motif: Potentiating apoptosis through IAP-binding. Cell Death Differ. 9: 93-95.

Shiozaki, E.N., Chai, J., Rigotti, D.J., Riedl, S.J., Li, P., Srinivasula, S.M., Alnemri, E.S., Fairman, R., and Shi, Y. 2003 Mechanism of XIAP-mediated inhibition of caspase-9. Mol. Cell 11: 519-527.

Sidman, C.L., Shaffer, D.J., Jacobsen, K., Vargas, S.R., and Osmond, D.G. 1993. Cell populations during tumorigenesis in Eu-myc transgenic mice. Leukemia 7: 887-895.

Silke, J., Hawkins, C.J., Ekert, P.G., Chew, J., Day, C.L., Pakusch, M., Verhagen, A.M., and Vaux, D.L. 2002. The antiapoptotic activity of XIAP is retained upon mutation of both the caspase 3- and caspase 9-interacting sites. J. Cell Biol. 157: $115-124$.

Silke, J., Kratina, T., Chu, D., Ekert, P.G., Day, C.L., Pakusch, M., Huang, D.C., and Vaux, D.L. 2005. Determination of cell survival by RING-mediated regulation of inhibitor of apoptosis (IAP) protein abundance. Proc. Natl. Acad. Sci. 102: 16182-16187.

Song, Z. and Steller, H. 1999. Death by design: Mechanism and control of apoptosis. Trends Cell Biol. 9: M49-M52.

Steller, H. 1995. Mechanisms and genes of cellular suicide. Science 267: 1445-1449.

Steller, H. 2008. Regulation of apoptosis in Drosophila. Cell Death Differ. 15: 1132-1138.

Strasser, A., Harris, A.W., Bath, M.L., and Cory, S. 1990. Novel primitive lymphoid tumours induced in transgenic mice by cooperation between myc and bcl-2. Nature 348: 331-333.

Sun, C., Cai, M., Gunasekera, A.H., Meadows, R.P., Wang, H., Chen, J., Zhang, H., Wu, W., Xu, N., Ng, S.C., et al. 1999. NMR structure and mutagenesis of the inhibitor-of-apoptosis protein XIAP. Nature 401: 818-822.

Sun, C., Cai, M., Meadows, R.P., Xu, N., Gunasekera, A.H., Herrmann, J., Wu, J.C., and Fesik, S.W. 2000. NMR structure and mutagenesis of the third Bir domain of the inhibitor of apoptosis protein XIAP. J. Biol. Chem. 275: 33777-33781.

Suzuki, Y., Nakabayashi, Y., and Takahashi, R. 2001. Ubiquitinprotein ligase activity of $\mathrm{X}$-linked inhibitor of apoptosis protein promotes proteasomal degradation of caspase-3 and enhances its anti-apoptotic effect in Fas-induced cell death. Proc. Natl. Acad. Sci. 98: 8662-8667.

Takahashi, R., Deveraux, Q., Tamm, I., Welsh, K., Assa-Munt, N., Salvesen, G.S., and Reed, J.C. 1998. A single BIR domain of XIAP sufficient for inhibiting caspases. J. Biol. Chem. 273: 7787-7790.

Tamm, I., Kornblau, S.M., Segall, H., Krajewski, S., Welsh, K., Kitada, S., Scudiero, D.A., Tudor, G., Qui, Y.H., Monks, A., et al. 2000. Expression and prognostic significance of IAPfamily genes in human cancers and myeloid leukemias. Clin. Cancer Res. 6: 1796-1803.

Thompson, C.B. 1995. Apoptosis in the pathogenesis and treatment of disease. Science 267: 1456-1462.

Thornberry, N.A. and Lazebnik, Y. 1998. Caspases: Enemies within. Science 281: 1312-1316.

Varfolomeev, E., Blankenship, J.W., Wayson, S.M., Fedorova, A.V., Kayagaki, N., Garg, P., Zobel, K., Dynek, J.N., Elliott, L.O., Wallweber, H.J., et al. 2007. IAP antagonists induce autoubiquitination of c-IAPs, NF-кB activation, and TNF $\alpha$ dependent apoptosis. Cell 131: 669-681.

Vaux, D.L. and Silke, J. 2003. Mammalian mitochondrial IAP binding proteins. Biochem. Biophys. Res. Commun. 304: 499-504.

Vince, J.E., Wong, W.W., Khan, N., Feltham, R., Chau, D., Ahmed, A.U., Benetatos, C.A., Chunduru, S.K., Condon, S.M., McKinlay, M., et al. 2007. IAP antagonists target cIAP1 to induce TNF $\alpha$-dependent apoptosis. Cell 131: 682-693.

Vucic, D. and Fairbrother, W.J. 2007. The inhibitor of apoptosis proteins as therapeutic targets in cancer. Clin. Cancer Res. 13: $5995-6000$.

Wang, S.L., Hawkins, C.J., Yoo, S.J., Muller, H.A., and Hay, B.A. 1999. The Drosophila caspase inhibitor DIAP1 is essential for cell survival and is negatively regulated by HID. Cell 98: 453-463.

White, E. 2001. Regulation of the cell cycle and apoptosis by the oncogenes of adenovirus. Oncogene 20: 7836-7846.

White, K., Grether, M.E., Abrams, J.M., Young, L., Farrell, K. and Steller, H. 1994. Genetic control of programmed cell death in Drosophila. Science 264: 677-683.

Wilson, R., Goyal, L., Ditzel, M., Zachariou, A., Baker, D.A., Agapite, J., Steller, H., and Meier, P. 2002. The DIAP1 RING finger mediates ubiquitination of Dronc and is indispensable for regulating apoptosis. Nat. Cell Biol. 4: 445-450.

Yang, Y.L. and Li, X.M. 2000. The IAP family: Endogenous caspase inhibitors with multiple biological activities. Cell Res. 10: 169-177.

Yang, Y., Fang, S., Jensen, J.P., Weissman, A.M., and Ashwell, J.D. 2000. Ubiquitin protein ligase activity of IAPs and their degradation in proteasomes in response to apoptotic stimuli. Science 288: 874-877.

Yin, X.M., Wang, K., Gross, A., Zhao, Y., Zinkel, S., Klocke, B., Roth, K.A., and Korsmeyer, S.J. 1999. Bid-deficient mice are resistant to Fas-induced hepatocellular apoptosis. Nature 400: $886-891$ 


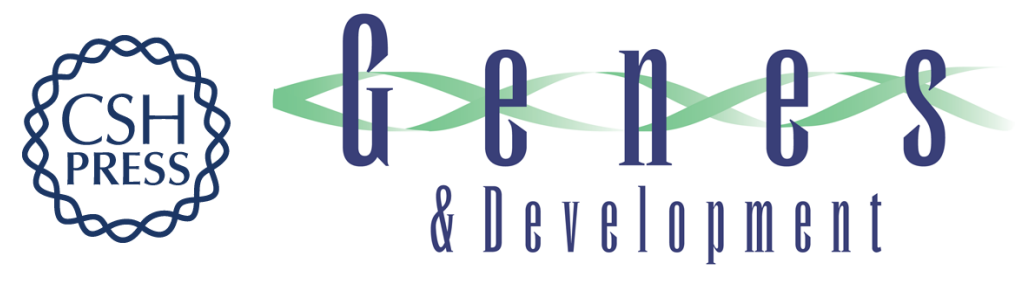

\section{Regulation of apoptosis by XIAP ubiquitin-ligase activity}

Andrew J. Schile, María García-Fernández and Hermann Steller

Genes Dev. 2008, 22:

Access the most recent version at doi:10.1101/gad.1663108

Supplemental

Material

References

This article cites 81 articles, 35 of which can be accessed free at:

http://genesdev.cshlp.org/content/22/16/2256.full.html\#ref-list-1

\section{License}

Email Alerting Service

http://genesdev.cshlp.org/content/suppl/2008/07/29/22.16.2256.DC1 right corner of the article or click here.

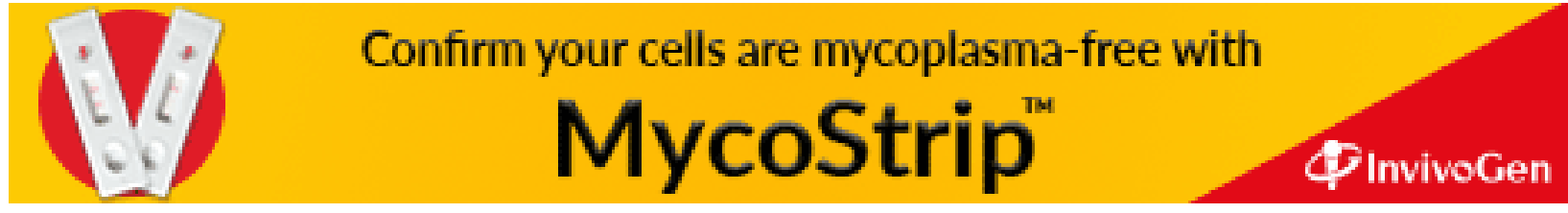

